\title{
Article
}

\section{Responsible governance in science and technology policy: Reflections from Europe, China and India}

Arnaldi, Simone, Quaglio, GianLuca, Ladikas, Miltos, O'Kane, Hannah, Karapiperis, Theodoros, Srinivas, Krishna Ravi and Zhao, Yandong

Available at http://clok.uclan.ac.uk/13729/

Arnaldi, Simone, Quaglio, GianLuca, Ladikas, Miltos ORCID: 0000-0001-79588975, O'Kane, Hannah, Karapiperis, Theodoros, Srinivas, Krishna Ravi and Zhao, Yandong (2015) Responsible governance in science and technology policy: Reflections from Europe, China and India. Technology in Society, 42 . pp. 81-92. ISSN 0160-791X

It is advisable to refer to the publisher's version if you intend to cite from the work. http://dx.doi.org/10.1016/j.techsoc.2015.03.006

For more information about UCLan's research in this area go to

http://www.uclan.ac.uk/researchgroups/ and search for <name of research Group>.

For information about Research generally at UCLan please go to http://www.uclan.ac.uk/research/

All outputs in CLoK are protected by Intellectual Property Rights law, including Copyright law. Copyright, IPR and Moral Rights for the works on this site are retained by the individual authors and/or other copyright owners. Terms and conditions for use of this material are defined in the policies page. 


\section{RESPONSIBLE GOVERNANCE IN SCIENCE AND TECHNOLOGY POLICY: REFLECTIONS FROM EUROPE, CHINA AND INDIA}

\section{ABSTRACT}

This Issues and Opinions Essay provides informed insights on developments and challenges related to responsible governance in the field of S\&T across Europe, China and India. The Essay presents an overview of policy debates and some key public policy documents in these three geopolitical areas and explores how responsibility is viewed and outlined in the policy domain. Moreover, considerations on the range of processes and actors affecting the relationship between science and society in China and India are presented. Finally, the Essay introduces Responsiveness as a possible ground of focus on comparative research work on responsibility in S\&T and relevant policy collaboration amongst the three regions.

1. Introduction: the ramping career of responsibility in science and technology governance $^{1}$

The notion of responsibility and the imperative of managing science and technology responsibly has gained considerable traction over the last decades. In the academic literature, the imperative of governing responsibly modern science and technology stretches back a few decades in diverse fields like ethics [2] and technology assessment

\footnotetext{
${ }^{1}$ The idea of this paper originated from a workshop entitled 'Responsible Governance of Science and Technology: perspectives from Europe, China and India' held at the European Parliament in Brussels, Belgium on March 19, 2014, to which all the Authors participated. The event was organised by the Science and Technology Options Assessment (STOA) Panel. The STOA Panel is the European Parliament's inhouse source of independent, balanced analysis of public policy issues related to S\&T. Its aim is to inform parliamentary debate and keep the Members of the European Parliament up-to-date with current and emerging S\&T issues and their policy implications. [1]
} 
[3-5]. It is however in the last decade that responsibility has gained an important access to science and technology policy, both moving into policy and funding programs and being the subject of the recommendations of authoritative advisory boards and respected scientific and the protagonists of policy and strategic documents issued by political institutions in fields like synthetic biology [6], geoengineering [7], or nanotechnology [811].

This emphasis on responsibility in S\&T draws on the established or emerging approaches looking at the encounters of science, technology and society as well as governing the complex trajectories that these encounters originated. Technology Assessment [12, 13], ethics of technology $[12,14]$, ethical, legal and social aspects (ELSA) studies of emerging technologies (e.g. [15]), anticipatory governance [16], socio-technical integration [17] are all examples of these efforts.

In essence, the current discussions on the responsible governance of science and technology derive and develop from these various approaches the importance to assess the societal issues of science and technology, so that their developments can be aligned to societal values and goals. Moreover, the responsible approach to science and technology governance incorporates the "upstream movement" that was initiated by its predecessors, viewing participation as a crucial instrument for incorporating societal views in policies and decisions about S\&T [18, 19].

Current debates and the present scientific literature on the responsible governance of S\&T and its forms are largely limited to experiences and approaches elaborated in Europe and North America. This Issues and Opinions Essay is a first attempt to explore responsible governance of science and technology beyond these boundaries and to include Asia in the picture. While it does not present the results of a specific research project, the Essay introduces some informed reflections of S\&T policy experts in the three regions with the aim to initiate a debate on the scope and possibilities of further comparative work leading 
to a better understanding of how the responsible governance of science and technology is perceived and can develop internationally . In doing so, the paper will present an initial comparison of the relevant policy debates in Europe, China and India. China and India have emerged both as significant players in the production of S\&T, new ideas and global knowledge. The European Union (EU), India and China are at different stages of economic and social development, but all face challenges with regard to the relationship between science and society. Developments in the three regions are related in terms of both collaboration and competition.

So far as S\&T policy is concerned, the EU has agreed on the common understanding that responsible governance should include social and ethical considerations in strategy and policy formulation, encompassing both expert and public opinion and utilising wide consultation processes. The current concept of Responsible Research and Innovation (RRI) has been developed from these ideas [20-23].

Although concept of RRI is not explicitly included as such in official Indian and Chinese S\&T policy, comparable ideas about responsible governance are being debated and have even started to appear in policy documents. For instance, in the national plan of science and technology in China, scientific development is still seen as the unquestioned driver of the country's economic performance but with a reference to responsible management and the right of society to take part in the discussions and decision making processes in S\&T [24]. Similarly in India, the 'Science, Technology and Innovation Policy 2013' document of the Indian Department of Science and Technology (DST) suggested that S\&T could be targeted at improving quality of life, stating that: "Science technology and innovation for the people is the new paradigm of the Indian science, technology and innovation policy" [25].

These official commitments are accompanied - and partially caused - by the vocal action of civil society, aiming to shape (and contest) technology policies and developments in 
these countries. As in Europe, recent public controversies in areas such as scientific misconduct, food safety and public health in China and India have proven to be a catalyst for S\&T debates. They have highlighted limitations in governance and have also begun eroding public trust in science $[26,27]$. This is particularly evident in debates on genetically modified crops whereby public debates initiated by civil society organisations in India and China were not only very similar in content and intensity to those in Europe but have also led to similar policy initiatives in GM food regulations and more importantly, they have initiated new decision making processes that highlight the need for more accountability and responsibility in governance [28]. In sum, views on the social implications of S\&T are increasingly being incorporated in the standard approach to analysing the advantages and disadvantages of new technologies, and systems of wider consultation have gained or are gaining policy acceptance in all these three regions.

Despite these commonalities, a closer look at the respective geographical context is needed to define concepts and strategies that can effectively explore this common interest in responsibility. This Essay presents reflections on responsible governance from the EU and the two emerging Asian economies of China and India, seeking to open the debate about the prerequisites, challenges, differences and possible convergences of responsible governance in the three regions.

The first section will provide background information on the scientific, technologic and economic contexts shaping the S\&T developments in the three regions. The second section will discuss the concept of responsible governance of $S \& T$, with a view to the current debate on RRI in Europe as it forms the main paradigm for the incorporation of responsibility in public policy in the EU. The third and fourth sections will present some considerations about the debate on responsible S\&T governance in China and India, along with the main challenges for its uptake in public policy. The final section will discuss the 
possible implications of the current trend for further research and policy collaboration amongst the three regions.

\section{Science, technology and the economy}

While the Essay has no ambition to provide a comprehensive comparison, the illustration of a few major data on the different scientific, technological and economic contexts can be useful to understanding the debates on and policies of responsible S\&T governance in China, India and the EU.

\section{1 European Union}

The EU originated with economic integration between countries in Europe, which aimed to end the devastating wars between them. Both economic and political integration have since deepened, with expansion from the six countries that founded the EU's predecessor in 1950, the European Coal and Steel Community, to the current twenty-eight Member States. In 1979, citizens were given the right to elect Members of the European Parliament directly. The year 1986 saw the introduction of the single market as the Single European Act was signed, the basis of the free flow of trade across Member States' borders. At the same time, the European Economic Community became the European Community as a recognition of increasing political ties. The European Community later became the EU, indicative of closer links between members enshrined in the Maastricht Treaty of 1993 and the Treaty of Amsterdam in 1999. In 2002, a new single currency, the Euro, was introduced in many Member States. Ten new countries joined the EU in 2004. 2009 saw the entry into force of the Treaty of Lisbon, intended to provide the EU with modern institutions and more efficient working methods. 
In recent years, the economic downturn has severely hurt Europe. In 2009, gross domestic product (GDP) fell in all EU Member States (with the exception of Poland) with a mean decrease of $4.5 \%$ (Figure 1) [29].

FIGURE 1 APPROXIMATELY HERE

Unemployment rates increased substantially from $7.2 \%$ in 2007 to $10.6 \%$ in January 2014, with even over a quarter of the active population unemployed in Spain and Greece. In parallel with the financial crisis, public confidence in the EU has fallen to low levels in the last years. The EU is the biggest trading partner in the world, followed by the United States and China [29]. The EU currently spends about 2\% of GDP on R\&D, which represents an annual expenditure of about EUR 245 billion (Figure 2) [32].

\section{FIGURE 2 APPROXIMATELY HERE}

The EU has adopted an ambitious strategy for S\&T that aims to make the region the world leader in both output quality and R\&D expenditure. Investing 3\% of the EU's GDP in R\&D, reducing the rates of early school leaving to below $10 \%$, and ensuring that at least $40 \%$ of 30-34-year-olds complete third level education are all objectives of the Europe 2020 strategy, the EU's growth strategy for the decade [33].

\subsection{China}

In China, before reforms and opening up started in 1978, the state-led S\&T system was very hierarchical. R\&D expenditure was concentrated in government institutions with few links to the market. Universities had almost no role in technological development or 
commercialization. By the late 1970s, the government recognised the low level of effectiveness of such a system and initiated a series of reforms to close the gap between China and Western countries. Reform of the economic system included the introduction of market pressures, rationalisation of the government-led economy, creation of spin-off high-technology companies and the import of technology (foreign firms were granted access to the domestic market in return for technology transfer) [34]. Nowadays, globalisation links Chinese companies to foreign customers, technology suppliers, and strategic partners. Economic openness has increased competition, forcing China to innovate and raise productivity. Notwithstanding these changes, China remains largely under central, top-down control.

China has seen tremendous development over the past two decades, with an average GDP growth of nearly 10\% per year (Figure 1). In 2005 the Chinese economy was half the size of the American economy. In 2011 it was 87\%. Considering China's 24\% economic growth from 2011 to 2014 compared to the American figure of $7.6 \%$, the Chinese economy is likely to overtake the United States economy this year $[35,36]$. China is the leading supplier of goods for the EU (17\%) and the second market for European goods [29]. This pace of development is mirrored in the S\&T sector: China now has the third largest R\&D investment budget in the world. According to the Scimago World Report 2013 (based on the period 2007-2011) the Chinese Academy of Sciences is the second ranked institution in the world for the number of scientific articles produced [37]. China is a world leader in many high-tech areas, such as biotechnologies and nanotechnology. However, the pace of change has created a host of social problems not unlike those seen in more advanced economies. The new-found ability to create economic wealth through S\&T developments has produced a general euphoria about S\&T but little discussion of its implications for everyday life. The management system of S\&T, characterised both by centralised bureaucracy in the public sector and deregulation in the private sector, creates additional 
barriers to an effective system of regulation [38]. Socio-economic inequalities produced by rapid economic development are another hindrance for S\&T.

\subsection{India}

Before the economy was opened in 1991, central planning, extensive regulatory controls, and widespread restrictions on foreign investment were the defining characteristics of the Indian economy [34]. The socialist vision of Nehru (prime minister from 1947 to 1964) gave way to an era of accelerated foreign direct investment, and economic and technical progress. India has emerged as one of the strongest developing economies in the world. The rate of GDP growth reached nearly $6 \%$ and stayed at this level for two decades. If the EU is not counted as a single unit, the Indian economy will become the third largest economy in the world before 2020 [39]. The EU and India are major trading partners. India is the EU's eighth largest export market [40]. According to the Economic Survey 2012-13, following the slowdown induced by the global financial crisis in 2008-09, the Indian economy responded strongly and achieved a growth rate of $8.6 \%$ and $9.3 \%$ respectively in 2009-10 and 2010-11, though the growth slowed down to 5.0\% in 2012-13 [41]. India's hi-tech exports increased from US\$ 10 billion in 2009 to US\$ 12.4 billion in 2012 [42]. Thus, it is very clear that S\&T is and will be playing a major role in the economic growth, particularly in the realm of international trade.

R\&D spending in India is low compared to Europe or China (Table 1).

\section{TABLE 1 APPROXIMATELY HERE}

The 12th Five-Year Plan for the period 2012-2017 proposes to increase R\&D expenditure to $2 \%$ of GDP. It also intends to increase the number of full-time researchers/scientists from the current level of 154,000 to 250,000 ; boost the volume of publication outputs in 
basic research from a global share of $3 \%$ to $5 \%$; improve the global publication ranking from 9th to 6th by the end of the 12th Plan; and focus on doubling the number of patents and increasing the commercialization of patent portfolio to 5-6\% from the current level of less than 2\% [43]. In addition, India's R\&D spending as a percentage of GDP has increased from $0.81 \%$ in 2005 to $0.87 \%$ in 2010 ; India's share in global research publications increased from 2.2\% in 2000 to 3.5\% in 2010 as per the SCl (Science Citation Index) database [44]. However, these achievements mask severe problems. For example, inequality continues to be of considerable importance, with a quarter of India's population living below the poverty line $[39,45]$. The country remains largely an agrarian economy, with roughly $50 \%$ of the work force employed in the agricultural sector. India has about 250 million adults who cannot read or write, literacy is declining slowly, and the percentage in higher education is low (Table 1). There are also problems in the S\&T sector; the Indian Institutes of Technology produce elite engineering graduates, but a large proportion of traditional universities are inadequate, with lack of autonomy and financial resources and a paucity of research output [46].

\section{Responsible governance in the European Union}

Over the past two decades, a series of events progressively undermined the legitimacy of EU S\&T governance, raising concerns over the social uptake of scientific-technological innovations [47]. Food crises in the 1990s, such as bovine spongiform encephalopathy ('mad cow disease') and the dioxin contamination scandal (with dioxin detected in animal food products, mainly eggs and chickens), undermined public confidence in regulatory procedures and expert-based policy-making [48]. A significant part of the European public considers GMOs to be the uncritical development of a potentially dangerous technology, whose risks were under-analysed [49]. These experiences forced European policy-makers 
to demonstrate to the public that the social and ethical principles behind publicly funded R\&D investments were adequately considered. In 'Science, society and the citizen in Europe', the EC argued that the relationships between S\&T and society "have to change because of the impact of science and research [...] on the quality of life in Europe" [50]. Philippe Busquin, European Commissioner for R\&D from 1999 to 2004, and later STOA Chair, stated that "democratic governance must ensure that social and economic issues are taken into consideration in research activities" [51]. In the execution of the European Commission's 'Science and Society Action Plan' which was launched in December 2001 [52], the European Commission (EC) appointed a high-level expert group to develop guidelines on genetic testing. The result of their work was published as ' 25 Recommendations on the ethical, legal and social implications of genetic testing' [53]. Within the Seventh Framework Programme for Research and Development of the European Union (FP7) running from 2007 to 2013, the European Commission published guidelines on responsible research and research ethics, and on the ethical reviews procedures for EU-funded research projects [54]. Following also the emerging broader international trends we have briefly referred to in the introduction (e.g. [6-9]), the European Commission went further to institutionalize the responsible governance of S\&T in its sector policies. Most prominently, the EC action plan on nanotechnology outlined a responsible strategy to integrate health, safety and environmental aspects and taking into account public opinion [10]. As part of this strategy, the EC issued a 'Code of Conduct for Responsible Nanosciences and Nanotechnologies' in 2008 [11], designed as an overarching responsibilisation framework for research and technology developments. Recent debates have considered nanotechnology's future $[55,56]$ and sought a new governance paradigm to anticipate and steer social reactions [16].

This attention to responsible governance was not restricted to the European institutions, but it was also prominent in some of the EU Member States. For instance, the UK Royal 
Society addressed the scientific and technical aspects of geo-engineering and advocated an adequate research governance framework to "guide the sustainable and responsible development of research activity", including the development of scientific codes of practice [7]. Similarly, the UK Engineering and Physical Sciences Research Council has developed a framework of responsible innovation in its funding scheme to incorporate knowledge about ethical acceptability and social needs in its research [57]. Also in the Netherlands, the Dutch Organization for Scientific Research (NWO) started a funding programme for responsible innovation in 2009. This programme encourages research where the ethical and social aspects of new technology are considered from the design phase onwards. This prevents adjustments having to be made in retrospect if society rejects the new technology [58].

\subsection{RRI: conceptual development and incorporation in the EU public policy}

The integration of responsible development in specific technological and scientific fields like nanotechnology has over the years accompanied the establishment of responsibility as a general feature of EU S\&T policy under the umbrella notion of RRI, i.e. the areas of work that were previously referred to as 'science in society' in EC are now called 'responsible research and innovation' [59]. RRI and its 'sister notion' of Responsible Innovation, have been defined in different ways [20-23]. Nevertheless, some common characteristics are discernible. These can be summarised in four features, following closely the definition proposed by Owen [22] and Owen et al. [23]:

- First, RRI is anticipatory, which means it should analyse potential impacts - both intended and unintended - including economic, social, and environmental aspects.

- Second, it is reflective, examining the underlying purposes, motivations and assumptions of research, and considering uncertainties and risks. 
- Third, RRI should be deliberative, which means it should open these issues and debates to broad deliberation and inclusive engagement.

- Finally, RRI should be responsive by using deliberation to influence the direction and pace of innovation.

As a "collective and continuous commitment" organised around these four aspects (anticipatory, reflective, deliberative and responsive), RRI steers innovation by incorporating considerations and knowledge about ethical acceptability and social needs [21]. RRI has the ambition to complement accounts of risk and precaution as an answer to the policy and regulatory dilemmas arising from techno-scientific fields whose impacts are poorly characterised or highly uncertain. In doing so, it takes a more proactive stance that seeks to answer the question: "what sort of future do we collectively want innovation to create for Europe?" [22].

From the broader movement towards public engagement in S\&T, RRI takes public participation and deliberation as the chief instruments to ensure that the two relevant dimensions of responsibility primarily involved in RRI are effectively in place: care and responsiveness [23]. Care implies the will and capacity to commit in the present for future societal needs and purposes, thus orienting research and innovation towards the future we want to live and they can help to create. Responsiveness implies the openness to the diverse views and knowledge in society, "both in terms of defining the targets for innovation and how its trajectory then evolves" ([23], 35). Responsiveness comes with deliberation, as a "widely configured" process, that "seeks not simply to understand views on the purposes and intended products of science and innovation and their acceptability, but that such engagement pro-actively helps establish and shape new agendas which set the direction of science and innovation themselves" ([23], 35).

\subsection{Incorporation of RRI into policy-making processes}


Formulated in the European academic and policy environment, the notion of RRI has enjoyed a remarkable degree of institutionalization in the EU science and technology policies. Horizon 2020, the most important EU programme for R\&D, is clearly focused on achieving the balance of supporting research and innovation and at the same time ensuring that the values and needs of society are taken into account. With the aim of expanding the relationship between science and society and reinforcing public confidence in science, "Horizon 2020 should foster the informed engagement of citizens and civil society in research and innovation matters by promoting science education, by making scientific knowledge more accessible, by developing responsible research and innovation agendas that meet citizens' and civil society's concerns" [60]. Horizon 2020 applies the RRI goal of orientating innovation towards social needs by establishing a 'challenge-based approach', whose ambition is to gather resources and knowledge from across different fields, technologies and disciplines to answer major EU policy priorities and social concerns (e.g. health, food security, clean energy, green transport, social inclusion, freedom and security).

RRI is one of the main cross-cutting issues of Horizon 2020, with an impact on all pillars and work programmes. The mainstreaming of RRI in Horizon 2020 is complemented by a dedicated programme called 'Science with and for Society'. This has the specific task to "develop the governance for the advancement of RRI by all stakeholders". Such a contribution will be targeted at the following key issues: i) engage society more broadly in research and innovation activities, ii) increase the access to scientific results, iii) ensure gender equality in both research programming and research content, iv) take account of the ethics dimension, and v) promote science education [61]. Several collaborative projects on RRI started under FP7 responding to Science in Society calls, such as Gest, Epinet, EST-Frame and Res-AgorA [62-65]. In this context, the private sector 
has also started to reflect on RRI; private funding agencies are an important part of a recently-started collaborative project on this subject covering 30 European countries [66].

In a complementary way to this broader EU push towards RRI, public national initiatives started to appear or have continued to function. For instance, the NWO's Responsible Innovation funding programme, which was one of the first cross-sector programmes on RRI, is on-going [58]. In the UK, a joint digital economy initiative by the national Research Councils has led to the appointment of a Responsible Innovation Advisory Panel. This explores the resources the digital economy and ICT research communities require to address RRI [67]. This is also the case for ethics advisory boards at the national and the European level, such as the European Group on Ethics in Science and Technology, appointed by the President of the EC, and the Committee on Bioethics, an intergovernmental body of the Council of Europe [68]. TA bodies are attached to national parliaments in ten EU Member States to advise parliaments on the possible social, economic and environmental impact of new science and technologies, while STOA fulfils the same role at the European Parliament [69]. Their roles and remit, particularly in relation to inclusive deliberation, mean that they are valuable in assisting the mainstreaming of RRI in the EU and ensuring its uptake in S\&T decision-making processes.

\section{Responsible Governance in China}

RRI is not a commonly used concept in Chinese S\&T governance. However, similar ideas, such as 'responsible research', 'ethics of science and technology', and 'science, technology and society' have for a long time been hot topics in both academic and social discussions $[70,71]$. Similar to Europe and other parts of the world, there is now a trend to emphasise more responsible research and innovation in China. 
The background to responsible S\&T governance in China can be summarised through three different concepts. The first is what in Chinese is called 'Developmentalism', which refers to the primacy of economic development for S\&T. Since reform and opening up in the late 1970s, promoting economic development has become the main priority, as indicated by the former Chinese leader Deng Xiaoping, "Development is the absolute principle" [38]. The principle of developmentalism significantly influenced the distribution of S\&T resources and the mode of S\&T development.

'Scientism' is the second commonly used descriptive concept. S\&T has been considered the driving force of economic and social development. The Chinese government has frequently emphasised the important role of S\&T in promoting social and economic development since reform and opening up. In 2012 the government declared the "innovation-driven development strategy", putting S\&T in the key position of the transformation of the economic development mode. Meanwhile, public attitudes towards S\&T have been positive in China. For instance, in a 2010 survey, $89 \%$ of the public agreed that "S\&T makes our lives healthier, easier and more comfortable" [72], whilst only 66\% of the European public agreed with that statement [73].

The third and final concept is the top-down management system. The traditional governmental policy-making system in China could be summarised as a typical top-down system where the government plays a dominant role in decision-making. Society is very weak compared to the strong state. As a result, public participation in S\&T policy-making has been rare.

The responsibility of S\&T has been limited to promoting China's economic growth, wealth and power. For many years, the social responsibility of S\&T has been neglected. However, great social changes have taken place in the last years that have increased concerns for scientific research and innovation and new arenas for the discussion of responsible S\&T have emerged. 
4.1 Responsible governance at public, scientific and governmental levels

Facing increasing problems around environmental pollution, resource shortages, social injustice and rising public calls for improved livelihoods and better social services, the Chinese government has acknowledged the limits of developmentalism and is actively changing the purely economic-oriented development mode into a more sustainable and inclusive one. Over the past decade, the Communist Party Central Committee and the State Council have put forward new concepts advocating a scientific outlook on development and improving society. In 2012, the Ministries of Science and Technology and of Finance launched the 'Science and Technology Program for Public Wellbeing', whose aim is to ensure that more people benefit from S\&T innovation [74].

Chinese policy-makers have also realised the limits of the top-down governmental management mode. Promoting innovation and involving all parties in social governance has become one of the major tasks of the current government. This has also been reflected in S\&T governance that has incorporated various modes of responsible S\&T governance as it is understood in Europe. For instance, when starting the compilation of the 'Outline of the National Program for Long-and-Medium-Term Scientific and Technological Development' in 2003, the government introduced multiple forms of public participation. As a result the Ministry of Science and Technology opened a new channel about the outline on its official website to keep the public informed of progress, and launched a public participation forum with 19 topics that the public could visit to make comments and share views on the compilation of the outline. In 2008, in order to promote public participation in the governance of GM food technology, the Chinese Academy of Science and the Xicheng district government in Beijing organised a consensus conference that provided a platform of open dialogue between the public and experts [75]. As part 
of the 'National Technology Foresight Report (2013-2014)' the Chinese Academy of Science and Technology is conducting an online public survey to collect data on the public's needs and their suggestions for future technology development in China.

Besides governmental strategies and policies, there are two additional and important levels at which the responsible governance debate has developed in China: the public and scientists. For the public, the rapid economic growth of the last thirty years has greatly improved living standards. As people's living conditions and level of education have rapidly increased, public awareness of rights and perception of risks have risen accordingly. As a result, the Chinese public has become more and more concerned about ethical issues in S\&T. For instance, in 2007 citizens in Xiamen, a city in south-eastern China, gathered to protest the plan to establish a p-xylene plant in a suburb because they feared it would pollute the environment. Despite the assurances of industry and local government, the citizens refused to accept the factory. Eventually, the local government gave up the plan and moved the plant to another city [76]. Similar protests have happened in recent years in other Chinese cities. In 2011, a senior researcher for a tobacco research institute was elected to the Chinese Academy of Engineering (CAE) for his achievement in providing technology to reduce tar content in tobacco. This election soon caused public debate. It was argued that technology to reduce tobacco tar was unethical as it might persuade more people to smoke, with the scientist seen as being in the service of the tobacco industry. Therefore, the CAE was asked to deprive the scientist of the title of academician [77]. Although the CAE did not remove him, it took measures to ensure that no more members of the tobacco industry would be admitted [78]. Concern about responsible governance of S\&T has also been demonstrated in public opinion research. The Chinese Academy of Science and Technology for Development conducted two rounds of surveys of citizens in five Chinese cities in 2007 and 2010. When asked "should scientists be responsible for the misuse of their research products?" $36 \%$ responded 
affirmatively in 2007 . In 2010 , this percentage increased to $46 \%$. The rising public perception of risk and concern for ethical issues in S\&T has led to higher requirements for responsible governance in China [79].

Among Chinese scientists, in the past discussions focused on the responsibility of scientists as members of the scientific community. As Chinese scientific research capacity grew rapidly, scientific morality and integrity faced more challenges as the scope and impact of scientific misconduct increased. In a 2008 national survey of 30,000 S\&T personnel, nearly half thought scientific misconduct was common in China, and more than half of respondents stated that they knew researchers around them who had committed scientific misconduct [80]. The scientific community in China has taken various measures to fight misconduct. For example, in 2007, the Chinese Association of Science and Technology formally issued 'The Norms of Scientific Ethics of Science and Technology Personnel' defining the principles of scientific morality, the scope of scientific misconduct, and the process to monitor scientific misconduct [81]. Increasingly, researchers have also become aware that their studies have social and ethical implications. In a survey on science ethics of researchers in China conducted in 2012, only $19 \%$ of respondents thought that no ethical issues were involved in their research [82].

\section{Responsible Governance of S\&T: an Indian perspective}

In the Indian context the state plays the leading role in deciding priorities in research, funding and the application of S\&T for development. In India, S\&T has been identified in the policy agenda since the 1950s as a key means to achieve national prosperity, both in terms of economic growth and social development. The Scientific Policy Resolution of 1958 clearly stated that "the key to national prosperity, apart from the spirit of the 
people, lies, in the modern age, in the effective combination of three factors, technology, raw materials and capital, of which the first is perhaps the most important, since the creation and adoption of new scientific techniques can, in fact, make up for a deficiency in natural resources, and reduce the demands on capital" [83]. The subsequent S\&T policies, namely the Technology Policy Statement of 1983, the Science and Technology Policy of 2003 and the most recent Science, Technology and Innovation Policy (STIP) of 2013, have reiterated the broad vision of 1958 while expanding and enriching it further [25,84,85]. The latest STIP 2013 categorically states that "science, technology and innovation (STI) have emerged as the major drivers of national development globally. As India aspires for faster, sustainable and inclusive growth, the Indian STI system, with the advantages of a large demographic dividend and the huge talent pool, will need to play a defining role in achieving these national goals. The national STI enterprise must become central to national development" [25]. The on-going national 12th Five-Year Plan (201217) also recognises that the objective of development is a broad-based improvement in the economic and social conditions of the people [43].

The Government on the other hand has been active in promoting the role of S\&T in national and social development. The Ministry of Science and Technology has launched a programme, Science for Equity Empowerment and Development (SEED). This aims to provide chances for scientists to run action-oriented and location-specific projects that use S\&T to improve the socio-economic situation of the poor and disadvantaged, particularly in rural areas [86].

\subsection{Public policy and civil society in responsible S\&T policy in India}

It has rightly been suggested by Mashelkar [87] that the four pillars underlying India's S\&T goals can be recognised as techno-nationalism, inclusive growth, techno-globalism and 
global leadership. Of particular relevance for responsible governance is the idea of inclusive growth, well established in Indian S\&T policies. The latest Science, Technology and Innovation Policy 2013 mentions "a strong and visible Science, Research and Innovation System for High-Technology-led path for India as the goal of the new STI Policy" and 'science, technology and innovation for the people' as the new paradigm of the Indian STI enterprise. It exhorts that the national STI system must, therefore, recognise the Indian society as its major stakeholder. "Innovation for inclusive growth implies ensuring access, availability and affordability of solutions to as large a population as possible" [25]. Thus, it can also be observed that the evolution of S\&T policies in India since the 1950s also reflects the change in the nature and mode of advancing new dimensions in the notion of 'responsible governance' of S\&T in India. This changed from the top-down approach in the early years, where the government on its own took responsibility for S\&T development and direction, to the inclusive approach, where the involvement of the 'entire Indian people' is aspired to, in terms of coordination at all levels with any sector of economic, scientific and technological activity.

Although it is not clear how the inclusive approach will be fully translated into action, there are some promising examples. One case is the discovery, development, and delivery of drugs and vaccines that are affordable, and accessible to the poor $[88,89]$. The Open Source Drug Discovery project is a similar initiative, started in 2007 by the Indian Council of Scientific and Industrial Research to develop drugs for tuberculosis using an open source approach. This project involves the participation of students, experts and researchers from both the public and private sectors, whereby data is collected and shared [90]. Another encouraging example is the evolution of Indian policies aimed at regulating genetically engineered agriculture. Through stakeholder debates it became clear that in India, agrifood innovation cannot be divorced from broader socioeconomic impacts (effects on small farmer communities, the environment, labour costs, traditional 
agriculture, etc.) while food security is a major preoccupation for policymakers. Food policy has been influenced by various interest groups and/or trade bodies for which socioeconomic issues are key value considerations. This appears to have produced a number of very pragmatic policy choices that aim to sustain and develop organic agriculture while at the same time making room for the sustainable implementation of biotechnology innovations. Where initial regulations emphasised human health and environmental impacts as a result of being heavily based on OECD sources, India expanded biosafety first to address the economic security of farmers, later increasing citizen participation and consultation [28].

Civil society has been able to play a role in steering S\&T governance, although the process could be further democratised to involve the increasing number of farmers using genetically engineered cotton crops in a debate currently being had on their behalf [91]. As it is the case in China, spontaneous public protest have proven a catalyst in the S\&T debates in the country. For instance, huge public protests were seen against the establishment of nuclear plants in various parts of India. Villagers, farmers and activists opposed the plants being built on the grounds of livelihood loss, health and environment hazards, and vulnerability to earthquakes. In the case of the proposed plant at Mithivirdi in Gujarat state, environmental experts and activists alleged that there were serious flaws in the Environment Impact Assessment carried out by the government body, Engineers India Limited [92].

\section{Dimensions of responsible governance}

The previous sections of the Essay illustrate some parallel tendencies in the China, India and the EU. They identify a common trend towards responsible S\&T governance, by aligning social needs and goals on the one hand, and science and innovation on the other 
hand. Similarly, they illustrate the (often conflictual) interaction between the science policy system and the public, an interaction that is nevertheless stimulating and creative. In an attempt to find a common denominator in these common developments, we find the notion of responsiveness, as the term best describing the commonalities in the three regions. Responsiveness refers to the capacity, commitment and practice of responding to societal demands in and by the science system and policy making. It signifies the process of incorporating lay values and opinions in societal debates and official decision making. In the present section, we introduce three main dimensions relevant for responsiveness that can serve as a guidance to explore commonalities and differences of responsible S\&T governance in these three different cultural and institutional settings.

Public participation: in the RRI literature, responsiveness is inextricably linked to deliberation and public participation [23]. While it would be inexact to affirm that the RRI literature reduces public participation to those forms that are institutionalized in policy making, especially in its public sponsored variety, the institutional environment in which RRI is developing (EU policy and, especially, its main research funding instrument Horizon 2020) frames public participation mostly within the broader framework of publicly sponsored projects and initiatives. As we have seen above, China and India share an interest in and are moving towards on institutionalized forms of public engagement, but an important element in building responsiveness of the science system is the spontaneous and less institutionalized action of citizens, be they organized in civil society organizations or (local) movements, who are vocally pushing societal view, needs and demands up the ladder of the political and scientific agenda. This plurality of the forms of public participation suggests the necessity to take a broader view of it, so that the many configurations participation assumes in diverse cultural and institutional contexts can be detected (see e.g. [93] on the varieties of public participation). 
Scientific literacy represents a significant problem when promoting public participation in S\&T governance. With regard to this, China confronts the fact that the proportion of people with basic scientific literacy accounts for only just over $3 \%$ of the Chinese population [72]. The level of economic development and education varies greatly among social classes, regions and ethnic groups. In such a large and diverse country, promoting public participation in S\&T governance will be a difficult task. India is similarly aware of the problems created by low levels of literacy. Setting aside science literacy in India, the overall literacy rate of India is only about 74\% [94]. This means that there is an urgent need for concerted efforts in increasing the literacy among the citizens, as well as scientific understanding. This has been one of the objectives of the Science and Technology strategy of 2003 , which stated that "one was to ensure that the message of science reaches every citizen of India" [85]. However, this effort of science communication and popularisation by government agencies, like the Department of Science and Technology and the Council of Scientific and Industrial Research (CSIR), rests most of the times on one-way communication approaches, in which citizens are expected to learn, appreciate and understand developments in science and the policies of the government, in a way that resembles closely the deficit model of public understanding of science.

Responsibilisation of the scientific community: responsiveness implies also a degree of active involvement and commitment of the actors involved in scientific research or innovation process, including, and primarily, the scientific community itself. We call responsibilisation this active commitment of social actors [95]. In this respect, China and India have experienced a significant protagonism of the respective scientific community. The push by scientific association to adopt a Code of ethics for Chinese scientists, as well as the widespread awareness that scientific research and technology development entail 
ethical and social issues points to the issue of responsibilisation and suggest some reasons for optimism. In India, programs like the Science for Equity Empowerment and Development (SEED) have created a framework in which scientists can tightly link their research activities to the achievement of societal goals. In the European Union, Horizon 2020 Science With And For Society program aims at creating a forum for scientists engagement with society to foster their active role in building RRI.

Intermediary bodies: both the evolution of the national research systems [96] and the diverse and multilayered configuration of the European Union made intermediary bodies and organizations proliferate and acquire an essential role in orienting European science policy. Ethics committees, technology assessment and foresight bodies, science councils, all are part of this thick network that play an important role in the promotion and development of responsible S\&T governance across Europe. As part of the science advisory system, they contribute to the inclusion of societal considerations in science and technology policy. Furthermore, the gradual stakeholder engagement turn that affected the activity of some of them, especially in technology assessment, creates important opportunities for broadening public participation. This thick layer of intermediary organizations is almost non existent in India and China but there is a strong will to develop them in the same line of remit as those in Europe.

\section{Conclusions}

Responsibility in S\&T governance via Responsiveness is an urgent common undertaking in all three regions. While innovation is still the dominant discourse in Chinese society, many policy-makers and scientists worry that emphasising the responsibility of research and innovation may impede China's S\&T development [97]. Promoting responsible S\&T governance will not only require reform of the S\&T governance system but also 
fundamental reforms of China's economic development and social governance system, such as changing the economic-focused development mode and including more public participation in the social governance system. Similarly, India is struggling to strike a balance between promoting innovation and ensuring that it is inclusive. In practice, this does not currently seem to be happening. Policy-makers in the Ministry of S\&T believe that the various tenets of ensuring inclusiveness can have adverse effects on science, technology and innovation potential. Proponents argue that it is high time that the various stakeholders who would be impacted by such science, technology and innovation exercises be informed and involved from the beginning, to bridge the gap between science and society. In the European Union, to live up to the expectations expressed in Horizon 2020, a concerted effort will be needed to increase RRI diffusion and effectiveness. The EC recently convened an Expert Group on the State of Art in Europe on RRI to assess alternative policy options for fostering RRI policies in Europe [21]. The Group report clearly identified the need to coordinate efforts in the EU as a crucial issue concerning RRI mainstreaming in research and policy as well as for its effective implementation, through, for instance, ad hoc funding or the adoption of RRI-related criteria for existing programmes. This is even more important in the EU governance context, which is by definition diverse and multi-layered.

This Issues and Opinions Essay has briefly presented some key aspects of public S\&T policy trying to highlight some crucial thematic aspects related to these efforts and processes converging towards the construction of responsible S\&T governance, its organization and its implementation in China, India and the European Union. The goal was not to outline a fully-fledged comparative analysis, but, more modestly, to propose some topics for further academic and policy debate. Responsiveness, i.e. the capacity, commitment and practice of responding to societal demands in and by the science system and policy making, has been chosen as an umbrella term to make sense of these interactions and as 
a guiding concept in the selection and presentation of these topics because it is at the heart of the alignment of science practice and policy on the one hand and society demands and goals on the other hand that is postulated by the RRI approach. Public participation, scientists responsibilisation, and intermediary organizations in the Science Advisory Systems have been identified as possible dimensions of responsibility along which analysis, comparison and collaboration can be organized. In suggesting these possible domains for a common endeavour, we are aware that responsible governance has to be developed within each particular cultural and need-based context.

As globalisation decisively interconnects S\&T developments around the world, steering research and technology for social goals requires a careful balance between global convergences and local differences. Overall, responsible governance represents a strong force of change internationally. The direction and form of change will depend on local norms and needs. Further in-depth research on the existing application of responsible governance in these three geographic areas is needed in order to achieve a shared understanding that might foster the establishment of common research programmes in the field. The conceptual and procedural aspects of change in practices and policies of responsible governance will require further international collaboration that would function in parallel to the significant S\&T collaboration that is currently taking place amongst the EU, China and India.

We hope this Essay can contribute to foster a robust scientific debate on this issue, which, in turn, can help promote international collaboration in the field of responsible S\&T governance. 


\section{Acknowledgements}

We are indebted to Gilles Laroche and Timea Balogh from the 'Science with and for Society' Unit, DG Research and Innovation, European Commission, for their input and valuable comments. We are also very grateful to Filippo Bramati, STOA trainee, for the collation of data and the preparation of tables and figures.

\section{Disclaimer}

The views expressed in this publication are the sole responsibility of the authors and do not necessarily reflect the views of the affiliated organisations.

\section{References}

[1] STOA. Science and Technology Options Assessment (2014) Responsible Governance of Science and Technology: perspectives from Europe, China and India. <http://www.europarl.europa.eu/stoa/cms/home/events/workshops/responsible> accessed 11 June 2014.

[2] Jonas, H. (1984) The Imperative of Responsibility. Chicago, IL: University of Chicago Press.

[3] Hellstrom, T. (2003) 'Systemic innovation and risk: technology assessment and the challenge of responsible innovation', Technology in Society, 25: 369-84.

[4] Decker, M. \& Ladikas, M. (2004, Eds)Bridges between Science, Society and Policy; Technology Assessment - Methods and Impacts. Springer Verlag, Berlin

[5] Owen, R., Baxter, D., Maynard, T. and Depledge, M. (2009) 'Beyond regulation: risk pricing and responsible innovation', Environmental Science \& Technology, 43: 69026.

[6] PCSBI - Presidential Commission for the Study of Bioethical Issues (2010) The ethics of synthetic biology and emerging technologies, <http://bioethics.gov/syntheticbiology-report> accessed 3 April 2014.

[7] Royal Society (2009) 'Geoengineering the climate: Science, governance and uncertainty', <http://royalsociety.org/policy/publications/2009/geoengineeringclimate/> accessed 3 April 2014.

[8] NNI - National Nanotechnology Initiative (2004) '2004 Strategic plan', <http://www.nano.gov/node/242> accessed 3 April 2014.

[9] NRC - National Research Council (2006) 'A Matter of Size: Triennial Review of the National Nanotechnology <http://books.nap.edu/catalog.php?record_id=11752> accessed 3 April 2014. 
[10] European Commission (2005) 'Communication from the Commission of the 07/06/2005 - Nanosciences and Nanotechnologies: An action plan for Europe 2005-2009', $<$ http://eur-lex.europa.eu/legal-

content/EN/TXT/HTML/?uri=CELEX:52005DC0243\&rid=2> accessed 3 April 2014.

[11] European Commission (2008) 'Commission Recommendation of 07/02/2008 on a code of conduct for responsible nanosciences and nanotechnologies research', < http://eurlex.europa.eu/legal-content/EN/TXT/HTML/?uri=CELEX:32008H0345\&from=EN > accessed 3 April 2014.

[12] Grunwald, A. (2011) 'Responsible innovation: Bringing together technology assessment, applied ethics, and STS research', Enterprise and Work Innovation Studies, 7: 9-31.

[13] Guston, D. H., and Sarewitz, D. (2002). Real-time technology assessment. Technology in Society, 23(4):93-109.

[14] Responsible research and innovation: The role of privacy in an emerging framework, Bernd Carsten Stahl, Science and Public Policy (2013) 40 (6): 708-716.

[15] Thompson P.B. (2010), "Ethical, Legal, and Social Issues (ELSI)", in Horig Priest S. (a cura di), Encyclopedia of Science and Technology Communication, London, Sage Publishing, pp. 271-274.

[16] Anticipatory Governance of Nanotechnology : Foresight, Engagement, and Integration, Barben, Daniel, Fisher Erik, Selin Cynthia, and Guston David H., Hackett, E. J., Amsterdamska O., and Lynch M.The Handbook of Science and Technology Studies : Third Edition, 979-1000, Cambridge, MA, MIT Press

[17] Midstream modulation of technology: governance from within, E Fisher, RL Mahajan, C Mitcham, Bulletin of Science, Technology \& Society 26 (6), 485-496

[18] Macnaghten, P.M., Kearnes, M.B. \& Wynne, B. (2005). Nanotechnology, governance, and public deliberation: What role for the Social Sciences? Science Communication 27(2): 268-291.

[19] Mejlgaard N. and Stares S. (2013) 'Performed and preferred participation in science and technology across Europe: Exploring an alternative idea of "democratic deficit"', Public Understanding of Science, 22: 660-73.

[20] von Schomberg, R. (2013) 'A Vision of Responsible Research and Innovation'. In: Owen, R., Heintz, M. and Bessant, J. (eds) Responsible Innovation, pp. 51-73. Chicester, UK: Wiley.

[21] van den Hoven, J., Jacob, K., Nielsen, L., Roure, F., Rudze, L., Stilgoe, J., Blind, K., Guske, A.-L. and Martinez Riera, C. (2013) Options for Strengthening Responsible Research and Innovation: Report of the Expert Group on the State of Art in Europe on Responsible Research and Innovation. <http://ec.europa.eu/research/sciencesociety/document_library/pdf_06/options-for-strengthening_en.pdf> accessed 11 June 2014.

[22] Owen, R. (2014) Responsible Research and Innovation: Options for research and innovation policy in the EU. <http://ec.europa.eu/research/innovationunion/pdf/expert-

groups/Responsible_Research_and_Innovation.pdf\#view=fit\&pagemode=none> accessed 11 June 2014.

[23] Owen, R., Stilgoe, J., Macnaghten, P., Fisher, E., Gorman, M. and Guston, D. H. (2013) 'A framework for responsible innovation'. In: Owen, R., Heintz, M. and Bessant, J. (eds) Responsible Innovation, pp. 27-50. Chichester, UK: Wiley.

[24] Ministry of Science and Technology (MOST), People's Republic of China (2008) Law of the People's Republic of China on science and technology progress. Ministry of Science and Technology. http://www.most.gov.cn/fggw/fl/200801/t20080108_58302.htm. Accessed 4 July 2014 
[25] DST. Department of Science and Technology (2013a) Science, Technology and Innovation Policy. New Delhi: Government of India.

[26] Zhao, Y. and Ma, Y. (2009) 'Public Trust and Risk Management from the Perspective of Food Safety', Taiyuan Science and Technology, 181/2: 6-8.

[27] Rerimassie V., Ma Y., Srinivas K.R. \& Ladikas, M. (2015) Public Perceptions of Science and Technology in Europe, China and India. In Ladikas M., Chaturvedi S., Zhao Y \& Stemerding D. (eds) Science \& Technology Governance and Ethics; A Global Perspective from Europe, India and China. Springer, Dodrecht.

[28] Coles D., Chaturvedi S., Li Q. \& Ladikas M. (2015) New Food Technologies in Europe, India and China. In Ladikas M., Chaturvedi S., Zhao Y \& Stemerding D. (eds) Science \& Technology Governance and Ethics; A Global Perspective from Europe, India and China. Springer, Dodrecht.

[29] Eurostat <http://epp.eurostat.ec.europa.eu/portal/page/portal/eurostat/home/> accessed 11 June 2014.

[30] World Bank (2014b) World Development Indicators. <data.worldbank.org> accessed 5 June 2014.

[31] UNESCO Institute for Statistics (2014) Higher education in Asia: Expanding Out, Expanding Up: The rise of graduate education and university research. <http://www.uis.unesco.org/Library/Documents/higher-education-asia-graduateuniversity-research-2014-en.pdf> accessed 11 June 2014.

[32] Eurostat (2014b) $\quad R \quad \& \quad$ D $\quad$ expenditure. <http://epp.eurostat.ec.europa.eu/statistics_explained/index.php/R_\%26_D_expen diture> accessed 11 June 2014.

[33] European Commission (2014) Europe 2020 targets. <http://ec.europa.eu/europe2020/europe-2020-in-anutshell/targets/index_en.htm> accessed 11 June 2014.

[34] Segal, A. (2008) 'Autonomy, security, and inequality: China, India, the United State, and the globalization of science and technology', Technology in Society 30: 423-28.

[35] World Bank (2014a) 2011 International Comparison Programme Summary Results. <http://siteresources.worldbank.org/ICPINT/Resources/270056$1183395201801 /$ Summary-of-Results-and-Findings-of-the-2011-InternationalComparison-Program.pdf> accessed 11 June 2014.

[36] Financial Times (2014) 'China overtakes the US: your questions answered', 30 April 2014. <http://blogs.ft.com/money-supply/2014/04/30/china-overtakes-the-us-yourquestions-answered/?catid=186\&SID=google> accessed 11 June 2014.

[37] SCImago Research Group (2013) SIR Global 2013 - Rank: Output: 2007-2011. <http://www.scimagoir.com/pdf/SIR\%20Global\%202013\%200.pdf> accessed 11 June 2014.

[38] Wan, G. (2008) Thirty Years Reform and Opening Up of Chinese Science and Technology. Beijing: Science Press (in Chinese).

[39] Narasimha R. (2008) 'Science, technology and the economy: An Indian perspective', Technology in Society, 30: 330-8.

[40] Sabbati, G. (2013) Library Statistical Spotlight: Analysis of EU-India trade. Brussels: Library of the European Parliament.

[41] GOI. Government of India, Ministry of Finance (2013) Economic Survey. New Delhi: Oxford University Press.

[42] World Bank (2013) The Little Data Book 2013 (Washington, DC: World Bank). <https://openknowledge.worldbank.org/bitstream/handle/10986/13205/978082139 8128.pdf?sequence=1> accessed 11 June 2014.

[43] GOI. Government of India (2012) 12th Five-Year Plan 2012-2017. Planning Commission. New Delhi: SAGE Publications India Pvt Ltd. 
[44] DST. Department of Science and Technology (2013b) R\&D Statistics 2011-12: At a Glance. New Delhi: Government of India.

[45] Ratchford, J. T. and Blanpied W. A. (2008) 'Paths to the future for science and technology in China, India and the United States', Technology in Society, 30: 211-33.

[46] Datta S. and Saad M. (2011) 'University and innovation systems: the case of India', Science and Public Policy, 38: 7-17.

[47] Rodríguez H., Fisher E. and Schuurbiers D. (2013) 'Integrating science and society in European Framework Programmes: trends in project-level solicitations', Research Policy, 42: 1126-37.

[48] Commission of the European Communities (2001) European Governance: A White Paper. Brussels, 25.7.2001, $\operatorname{COM}(2001), 428$ final.

[49] EGE. European Group on Ethics in Science and New Technologies (2009) Opinion No. 24: Ethics of modern developments in agricultural technologies: Brussels, 17 December 2008. Luxembourg: Office for Official Publications of the European Communities.

[50] Commission of the European Communities (2000) Science, society and the citizen in Europe. Brussels, 14.11.2000, SEC(2000) 1973.

[51] Busquin P. (2003) 'Foreword'. In: Directorate-General for Research, European Commission. The overall socio-economic dimension of community research in the fifth European Framework Programme: A synthesis report on the integration of the socioeconomic related research activities of the European Community (1998-2002) (EUR 20577), p. 6. Office for Official Publications of the European Communities: Luxembourg.

[52] European Commission (2002) Science and Society Action Plan. <http://ec.europa.eu/research/science-society/pdf/ss_ap_en.pdf> accessed 6 June 2014.

[53] European Commission (2004) 25 Recommendations on the ethical, legal and social implications of genetic testing (Brussels: Directorate-General for Research, European Commission). <http://ec.europa.eu/research/conferences/2004/genetic/pdf/recom mendations_en.pdf $>$ accessed 11 June 2014.

[54] European Commission (2013) Ethics for researchers: Facilitating Research Excellence in FP7

(Brussels: Directorate-General for Research and Innovation, European Commission). <http://ec.europa.eu/research/participants/data/ref/fp7/89888/ethics-forresearchers_en.pdf> accessed 11 June 2014.

[55] Nordmann, A. and Rip, A. (2009) 'Mind the gap revisited', Nature Nanotechnology, 4: 273-4.

[56] Grunwald, A. (2007) 'Converging technologies: Visions, increased contingencies of the conditio humana, and search for orientation', Futures, 39: 380-92.

[57] Owen R. (2014a). The UK Engineering and Physical Sciences Research Council's Commitment to a Framework for Responsible Innovation. Journal of Responsible Innovation 1(1): 113-117.

[58] NWO. Netherlands Organisation for Scientific Research (2014) Responsible innovation programme. $<$ http: / /www.nwo.nl/en/research-andresults/programmes/responsible+innovation> accessed 11 June 2014.

[59] Stilgoe J., Lock S. J. and Wilsdon J. (2014) 'Why should we promote public engagement with science', Public Understanding of Science, 23: 4-15.

[60] Official Journal of the European Union (2013a) Regulation (EU) No 1291/2013 of the European Parliament and of the Council of 11.12.2013 establishing Horizon 2020 - the Framework Programme for Research and Innovation (2014-2020) and repealing Decision No 1982/2006/EC. 
[61] Official Journal of the European Union (2013b) Council Decision of 3 December 2013 establishing the specific programme implementing Horizon 2020 - the Framework Programme for Research and Innovation (2014-2020) and repealing Decisions 2006/971/EC, 2006/972/EC, 2006/973/EC, 2006/974/EC and 2006/975/EC, Part V, letter (f).

[62] GEST. Global Ethics in Science and Technology (2011) Gest: Global Ethics in Science and $\quad 2011 \quad 2014$. <http://www.uclan.ac.uk/research/environment/projects/global_ethics_science_te chnology.php> accessed 11 June 2014.

[63] Epinet (2012) The Epinet Project. <http://www.epinet.no> accessed 11 June 2014.

[64] EST-Frame (2012). Integrated EST framework (EST-Frame). <http://estframe.net/> accessed 11 June 2014.

[65] Res-AgorA. Responsible Research and Innovation in a Distributed Anticipatory Governance Frame. A Constructive Socio-normative Approach (2013) About Res-AgorA. <http://res-agora.eu/about/> accessed 11 June 2014.

[66] IrsiCaixa (2014) IrsiCaixa and "la Caixa" Foundation lead RRI Tools, a project performed in 30 european countries to foster a new relationship between science and European society. <http://www.irsicaixa.es/ca/node/12262> accessed 11 June 2014.

[67] Research Councils UK (2014) Responsible Innovation (Ethics). <http://www.rcuk.ac.uk/research/xrcprogrammes/digital/impact/responsibleinnov ation/> accessed 11 June 2014.

[68] Mali, F., Pustovrh, T., Groboljsek, B. and Coenen, C. (2012) 'National Ethics Advisory Bodies in the Emerging Landscape of Responsible Research and Innovation', Nanoethics, 6: 167-84.

[69] EPTA (2014) European Parliamentary Technology Assessment (EPTA). <http://eptanetwork.org/> accessed 11 June 2014.

[70] Zhu, B. (2000) 'Science and Technology Ethics: Justice and Responsibility', Philosophical Trends, 10: 9-11 (in Chinese).

[71] Xiao, X. (2010) 'Thirty Years of Science, Technology and Society Studies in China', Studies in Dialectics of Nature, 26/10: 69-76 (in Chinese).

[72] Ren, Fujun (ed.) (2011) Chinese Public Scientific Literacy Report, Volume 2. Beijing: Popular Science Press (in Chinese).

[73] European Commission (2007) Work Programme 2007, Capacities, Part 5: Science. In Society $(C(2007) 563$ of 26.02.2007). Brussels: The Seventh Framework Programme.

[74] MOST. Ministry of Science and Technology of China (2012) Science and Technology Program for Public Wellbeing. <http://www.kjhm.org.cn/www/STBPP/index.html> accessed 11 June 2014 (in Chinese).

[75] Li, Q., Zhao, Y. and Zhang, W. (2012) 'Public Participation in Science and Technology Ethical Issues in China'. In: GEST (ed.), Ethics State-of-the-Art: State of Debate in the Three Regions, pp. 37-

45.<http://www.uclan.ac.uk/research/environment/projects/assets/cpe_gest_D1_2 .pdf $>$ accessed 11 June 2014.

[76] Xie, L. (2013) 'PX Event in Xiameng: the Beginning of Chinese NIMBY Movement', Chinese Newsweek, 600/6: 78-9 (in Chinese).

[77] Shang, X. (2011) 'The election of "Tobacco Academician" has been widely questioned', Beijing Times 12 Dec. <http://epaper.jinghua.cn/html/201112/12/content_740361.htm> accessed 11 June 2014 (in Chinese).

[78] Global Times (2013) 'Fall of the killer academician', 27 March. <http://www.globaltimes.cn/content/771137.shtml> accessed 11 June 2014.

[79] Ma, Y., Zhang, W. and Zhao, Y. (2013) 'Change of Public Attitudes towards Science and Technology Ethics', Internal Report of Chinese Academy of Science and Technology for Development, 41 (in Chinese). 
[80] Zhao, Y. and Deng, D. (2012) 'Chinese Science and Technology Personnel's Views on Scientific Misconduct: Findings from a Survey on 30000 Science and Technology Personnel,' Science Research Management, 8: 90-7 (in Chinese).

[81] CAST. Chinese Association of Science and Technology (2009) The Norms of Scientific Ethics of Science and Technology Personnel. <http://www.cast.org.cn/n35081/n11114910/n11574863/11578899.html> accessed 11 June 2014.

[82] Zhang, L., Fang, Y., Yang, D. and Wang, L. (2013) 'A Survey on Science Ethics of Researchers', Bulletin of National Natural Science Foundation of China, 27/4: 210-3 (in Chinese).

[83] DST. Department of Science and Technology (1958) Scientific Policy Resolution. New Delhi: Government of India.

[84] DST. Department of Science and Technology (1983) Technology Policy Statement. New Delhi: Government of India.

[85] DST. Department of Science and Technology (2003) Science and Technology Policy. New Delhi: Government of India.

[86] DST. Department of Science and Technology (2014) Science For Equity Empowerment and Development (SEED). <http://www.dst.gov.in/scientificprogramme/s-t_ssp.htm> accessed 11 June 2014.

[87] Mashelkar R. A. (2008) 'Indian science, technology, and society: The changing landscape', Technology in Society, 30: 299-308.

[88] Havlir D. V. and Hammer S. M. (2005) 'Patents versus patients? Antiretroviral therapy in India', New England Journal of Medicine, 353: 749-51.

[89] Satyanarayana, K. and Srivastava, S. (2010) 'Patent pooling for promoting access to antiretroviral drugs (ARVs): a strategic option for India', Open AIDS Journal, 4: 41-53.

[90] Open Source Drug Discovery (2014) Open Source Drug Discovery. <http://www.osdd.net/> accessed 11 June 2014.

[91] Freeman J., Satterfield T. and Kandlikar M. (2011) 'Agricultural biotechnology and regulatory innovation in India', Science and Public Policy, 38: 319-31.

[92] Hindu (2013) 'Serious gaps' in EIA of Mithivirdi nuclear plant', 11 March. <http://www.thehindu.com/news/national/serious-gaps-in-eia-of-mithivirdinuclear-plant/article4496248.ece> accessed 11 June 2014.

[93] 2007, Science and Public Participation, in E.J. Hackett, O. Amsterdamska, M. Lynch and J. Wajcman (eds) "The Handbook of Science and technology Studies" (Third edition), Boston, The MIT Press (co-autore M. Bucchi), pp.449-472)

[94] GOI. Government of India (2011) Census of India. <http://www.censusindia.gov.in> accessed 11 June 2014.

[95] Dorbeck-Jung B., Shelley-Egan C. (2013), "Meta-Regulation and Nanotechnologies: The Challenge of Responsibilisation Within the European Commission's Code of Conduct for Responsible Nanosciences and Nanotechnologies Research", Nanoethics, Vol. 7, No. 1, p.55-68.

[96] van der Meulen, B., Rip, A. (1998), "Mediation in the Dutch science system", Research Policy, 27, 757-769.

[97] Zhang, W. and Zhao, Y. (2014) 'Innovation, risk and control: Three main discourses in the development of Synthesis Biology in China'. In: Chinese Academy of Science (ed.) 2014 High Technology Development Report, pp. 320-37. Beijing: Science Press. 
Table 1

Selected demographic and economic data for the EU, China and India, 2011-2014

\begin{tabular}{|c|c|c|c|}
\hline & EU & China & India \\
\hline \multicolumn{4}{|l|}{ People } \\
\hline Population (million) & $505.6^{\mathrm{a}}$ & $1,334.1^{b}$ & $1,241.5^{b}$ \\
\hline Population under 15 (\%) & $15.6^{\mathrm{a}}$ & $18.0^{\mathrm{b}}$ & $29.4^{b}$ \\
\hline Life expectancy at birth (years) & $80.5^{a}$ & $73^{b}$ & $65^{b}$ \\
\hline Under-five mortality rate (per 1000 live births) & $4^{c}$ & $15^{\mathrm{c}}$ & $61^{\mathrm{c}}$ \\
\hline Tertiary Education (\%) & $36.8^{\mathrm{a}}$ & $26.7^{\mathrm{b}}$ & $23.3^{\mathrm{b}}$ \\
\hline \multicolumn{4}{|l|}{ Economy } \\
\hline GDP/capita (US\$) & $32,817.332^{\mathrm{a}}$ & $9,083.2^{b}$ & $3,869.7^{b}$ \\
\hline Agricultural employment (\%) & $5^{a}$ & $35^{\mathrm{b}}$ & $47^{\mathrm{b}}$ \\
\hline Military spending (\% GDP) & $1.55^{\mathrm{a}}$ & $2.0^{\mathrm{b}}$ & $2.4^{\mathrm{b}}$ \\
\hline Starting a business (days) & $13^{b}$ & $33^{b}$ & $27^{b}$ \\
\hline High-technology export (\% of manufactured exports) & $15^{c^{*}}$ & $26^{c}$ & $7^{c}$ \\
\hline Energy use/capita (kg oil equiv.) & $3,322.8^{\mathrm{c}^{*}}$ & $2,029^{b}$ & $614^{b}$ \\
\hline Individuals using the Internet (\%) & $73.4^{c^{*}}$ & $38.3^{c}$ & $10.1^{c}$ \\
\hline \multicolumn{4}{|l|}{ R\&D } \\
\hline Expenditure for R\&D (\%) & $2.06^{\mathrm{a}}$ & $1.84^{\mathrm{b}}$ & $0.81^{d}$ \\
\hline Researchers in R\&D (per million people) & $2,924^{b}$ & $963^{b}$ & $160^{d}$ \\
\hline
\end{tabular}

Source a: [29]; b:[30]; c:[42]; d:[31]; *:Euro Area. 
EMBED MSGraph.Chart.8 Is

Figure 1. GDP of the EU, China and India 2004-2014 (billions US \$) Source: $[29,30]$. 
EMBED MSGraph.Chart.8 \s

Figure 2. R\&D as percentage of GDP of the EU, China and India, 2003-2011 Source: [30, 31]. 